\title{
Occurrence of mylonite zones and pseudotachylyte veins around the base of the upper crust: An example from the southern Hidaka metamorphic belt, Samani area, Hokkaido, Japan
}

\author{
Koji Shimada ${ }^{1}$, Hidemi Tanaka ${ }^{1}$, Tsuyoshi Toyoshima ${ }^{2}$, Tomohiro Obara ${ }^{3}$, and Tadafumi Niizato \\ ${ }^{1}$ Department of Earth and Planetary Science, The University of Tokyo, Hongo, Tokyo 113-0033, Japan \\ ${ }^{2}$ Department of Geology, Niigata University, Igarashi, Niigata 950-2181, Japan \\ ${ }^{3}$ Japan Oil Development Co. Ltd., Shinkawa, Tokyo 114-0033, Japan \\ ${ }^{4}$ Horonobe Underground Research Center, Japan Nuclear Cycle \\ Development Institute, Horonobe, Hokkaido 098-3297, Japan
}

(Received May 31, 2004; Revised December 28, 2004; Accepted December 29, 2004)

\begin{abstract}
Geological studies on exhumed pseudotachylyte-bearing mylonite zones in S-type tonalite were carried out in the southern Hidaka metamorphic belt, Hokkaido, Japan. Mylonitization is characterized by (1) development of composite planar fabrics, (2) grain size reduction, and (3) change in modal composition an increase in mica content and a decrease in quartz content from protolith to mylonite. Mylonite zones are heterogeneously concentrated in the host rocks. At microscopic scales, shear deformation is concentrated heterogeneously in finegrained layers along $\mathrm{C}$-surfaces. Most of the pseudotachylyte layers are subparallel to the $\mathrm{C}$-surface, and tend to overprint thick mylonite zones. The heterogeneous development of mylonite zones, which may be activated as layers of co-seismic slip, should be incorporated into numerical modeling of seismogenic zones.
\end{abstract}

Key words: Pseudotachylyte, mylonite, strain localization, Hidaka metamorphic belt.

\section{Introduction}

Geological investigations with a high spatial resolution on fault zones provide basic information for the spatial and historical understanding of fault activity. The Hidaka metamorphic belt (HMB) is an exhumed crustal section of an island arc formed during early Paleocene to Miocene (e.g., Komatsu et al., 1994; Owada et al., 1997), where relatively fresh fault zones formed within the deep crust are exposed (e.g., Toyoshima et al., 1994). A huge volume of S-type tonalite was intruded along largescale shear zones in preexisting metamorphic rocks subsequent to peak metamorphism (e.g., Toyoshima, 1991; Shimura, 1992; Toyoshima et al., 1994). This paper describes the occurrences and the meso- to microstructures of mylonites and pseudotachylytes in these tonalitic rocks.

Detailed geological mapping indicates that thin mylonite zones and associated pseudotachylyte veins are widespread in the southern HMB (Toyoshima et al., this issue). Pseudotachylytes and mylonites are well exposed along the Shimono-sawa route in the S-type tonalite. The exposures examined are located about $10 \mathrm{~km}$ east of the Hidaka Main Thrust, and the rocks exposed there have escaped intense cataclasis and alteration. They are therefore fitted to the study of fault structures in this seismogenic zone of the island arc crust.

Copy right(c) The Society of Geomagnetism and Earth, Planetary and Space Sciences (SGEPSS); The Seismological Society of Japan; The Volcanological Society of Japan; The Geodetic Society of Japan; The Japanese Society for Planetary Sciences; TERRAPUB

\section{Shear Zone Development in the Shimono-sawa Route}

The occurrence of fault rocks along the Shimono-sawa route was precisely examined at $1 / 1000$ scale (Fig. 1). The extent of mylonitization was tentatively ranked according to the shear plane separation interval by visual assessment using a ruler, as follows: mylonite $<1 \mathrm{~cm}$; protomylonite $<3 \mathrm{~cm}$; mylonitic tonalite $<5 \mathrm{~cm}$; and protolith $>5 \mathrm{~cm}$. These tentative field names used in this work do not correspond to the Sibson's definition (Sibson, 1977) but they are in qualitative accordance with the mylonitic characteristics of development of foliation and lineation (e.g., Tullis et al., 1982). The changes in microstructure are a grain size reduction and a shape preferred orientation of mica grains that defines the foliation (S-surface) in mylonitic tonalite (Fig. 2(b)). Protomylonite and mylonite are characterized by the development of S-C' and S-C-C' composite planar fabrics and a porphyroclastic texture accompanied by grain size reduction (Figs. 2(c) and (d)). Localized shear surfaces $\left(\mathrm{C}\right.$ and $\left.\mathrm{C}^{\prime}\right)$ in mylonite contain finegrained biotite and associated muscovite, chlorite, plagioclase, and quartz. The sizes of these fine-grained minerals are for the most part $<10 \mu \mathrm{m}$. An alternation of sheet silicate-rich layers and relatively coarse-grained quartzo-feldspatic layers is characteristically observed in mylonite and protomylonite. Porphyroclasts of plagioclase are frequently accompanied by quarter mats (Hanmer and Passchier, 1991) of muscovite (Fig. 2(e)).

The foliation in the protolith and the mylonite strikes concordantly NNW-SSE and dips to the ENE (Fig. 1). The mylonitic shear sense deduced from asymmetric mi- 


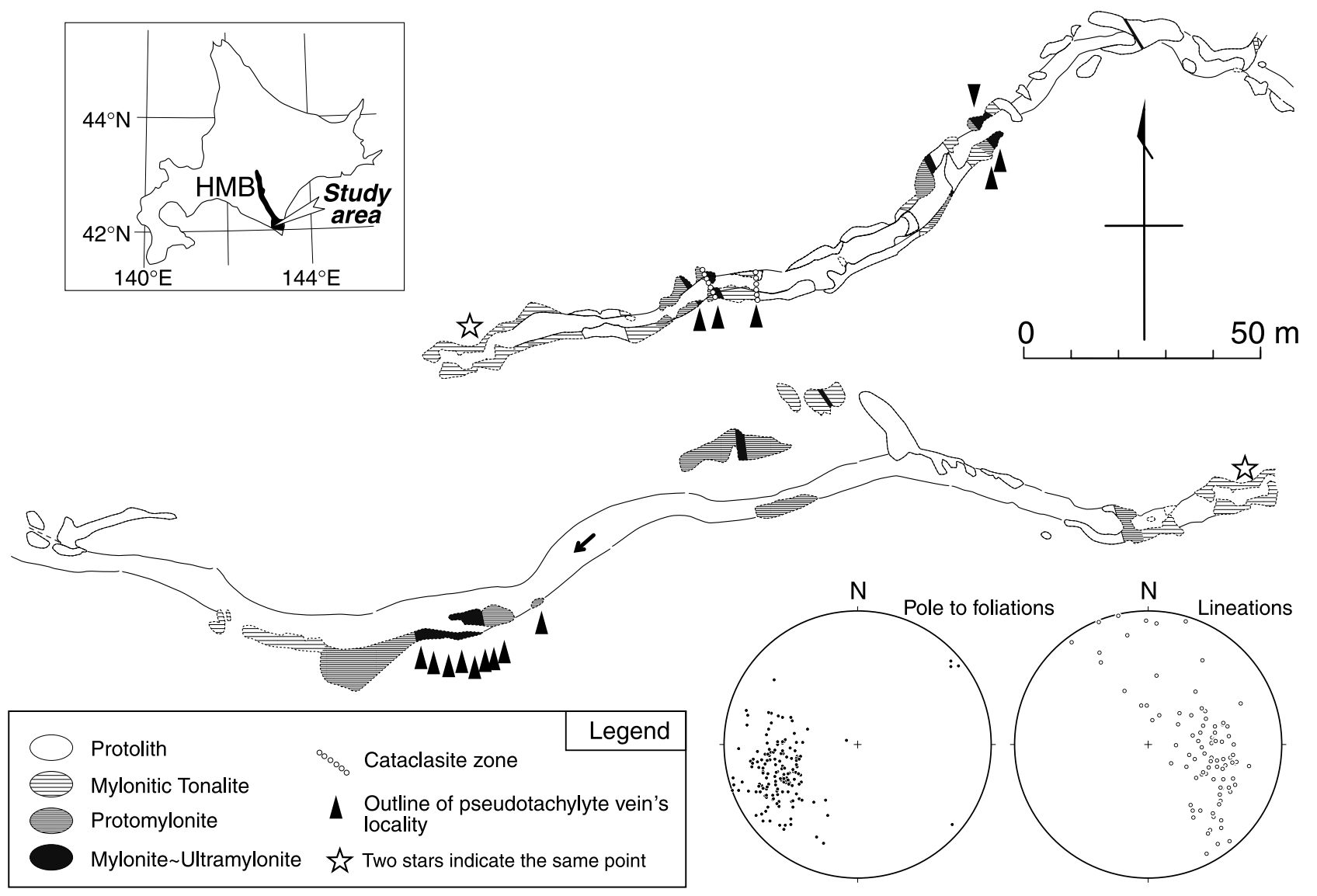

Fig. 1. A detailed map of fault rock distribution along the Shimono-sawa route, Samani area, southern Hidaka metamorphic belt, based on $1 / 1000$ scale surveys.

crostructures along the Shimono-sawa route is top-to-theeast. The fault rock distribution along the examined route is schematically shown in Fig. 3. Mylonite zones are clustered in the columnar section (Fig. 3). There are three clusters of ca. 20 to $100 \mathrm{~m}$ in thickness (shear zone A, B, and C). Outcrops are absent in some places along the route, and the longest such barren stretch is about $40 \mathrm{~m}$ (Fig. 1). These barren stretches are omitted from Fig. 3.

To check the ranking mylonitic lithology, the grain sizes of rocks were roughly estimated by the line-intercept method (e.g., Nicolas and Poirier, 1976). Thin sections were prepared from specimens parallel to lineation and normal to foliation (XZ section). Over 100 grain-boundaries were counted under an optical microscope along lines normal to the mylonitic foliation. Thereafter, grain-size index values were calculated as line length/grain number. These data are plotted in Fig. 3. The classification of mylonitic rocks in the field, varying from protolith to mylonite, seems to be consistent with a gradual decrease of grain-size index value as measured under the microscope with $\times 10$ and $\times 40$ objective lenses (Figs. 3 and 5). The grain-size index of mylonite is typically less than ca. $20 \mu \mathrm{m}$, being largely distinct from that of other fault rocks. Abundant fine-grained sheet silicate minerals of less than a few microns in size contribute to the small grain-size index values of mylonite.

Mylonitization in the Shimono-sawa route is characterized not only by the developments of shear surfaces and grain size reduction but also by a change of modal composi- tion (Fig. 4). Data from mylonite zones A and C (Fig. 3) and the surrounding rocks were obtained by conventional point counting under an optical polarized microscope (400-1000 points for each thin section). The confidence limits for the counted proportion of each mineral phase are less than $5 \%$. In the case of fine-grained mylonite, precise identification of minerals was partly obstructed due to their fine grain size $(<10 \mu \mathrm{m})$. Microstructural observations using SEM, for example, will be necessary in the future. The optical properties used to identify fine-grained minerals are as follows: Quartz and feldspars were identified by the difference of refractive index $\left(R I_{\text {minerals }}\right)$ under plane polarized light using a $\times 40$ objective lens $\left(R I_{\text {plagioclase }} \geq R I_{\text {quartz }} \geq R I_{\text {Kfeldspar }}\right)$. Sheet silicates were identified by pleochroism and interference colors. Finegrained biotite and muscovite, however, are hardly distinguishable because of the pleochroism of muscovite containing Fe. Chlorite shows no to weak pleochroism from pale yellow to pale brown with a very low interference color. Based on these ambiguities, modal compositions are described semi-quantitatively, and the modal contents of biotite and muscovite are shown as a sum of them.

From the protolith to mylonite, the total modal content of sheet silicate (biotite+muscovite+chlorite) increases gradually from ca. $20 \%$ to, in part, over $60 \%$ (Fig. 5(a)), and quartz decreases from ca. $40 \%$ to $10 \%$ (Fig. 5(b)). In contrast, the modal contents of each sheet silicate mineral vary widely, although chlorite contents are characteristi- 

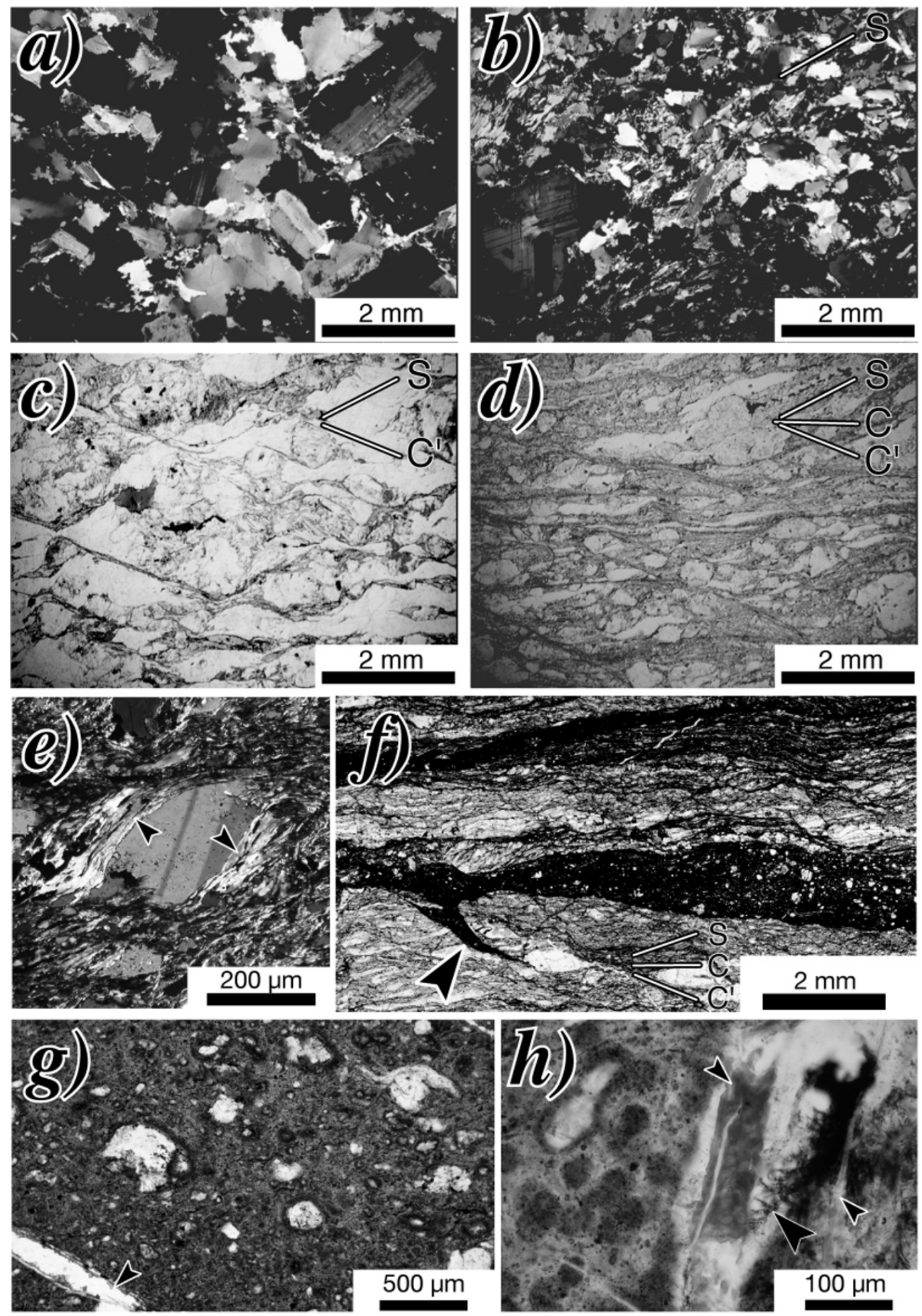

Fig. 2. Photomicrographs showing development of mylonitic microstructure from protolith to mylonite (a-e) and pseudotachylyte (f-g), under crossed polarized light ( $a, b$ and e) and plane polarized light (c, d, f, g and h). (a) S-type tonalite as a protolith. Alignment of coarse-grained euhedral plagioclase, biotite and minor amounts of muscovite defines a weak foliation. Quartz is partly recrystallized by weak mylonitization. (b) Mylonitic tonalite, characterized by partly developed recrystallized and fine-grained quartz and mica. Preferred orientation of mica defines the S-surface. (c) Protomylonite. A well-developed $\mathrm{C}^{\prime}$-surface is defined by alignment of fine-grained mica. The $\mathrm{S}$-surface is defined by the arrangements of plagioclase, quartz aggregates, and mica. A composite planer fabric (S-C' fabric) indicates a dextral sense of shear corresponding to normal dip-slip at the outcrop. (d) Mylonite characterized by grain size reduction. Well developed C-surfaces as well as $\mathrm{C}^{\prime}$-surfaces are characterized by fine-grained mica. The S-surface is defined by alignment of plagioclase and lenticular-shaped quartz aggregates. A composite planer fabric (S-C-C' ${ }^{\prime}$ fabric) indicates a dextral sense of shear (normal dipslip). (e) An example of quarter mats structure (arrowheads) composed of muscovite adjacent to a plagioclase porphyroclast. (f) An example of pseudotachylyte vein. Angular to rounded fragments and very fine-grained opaque minerals are suspended in a cryptocrystalline matrix. Generation veins are subparallel to the C-surface of the mylonite. Some injection veins (an arrow) are emplaced along pre-existing $\mathrm{C}^{\prime}$-surfaces although most of them cut mylonitic fabrics at a high angle. (g) Microlitic texture in a thicker vein of pseudotachylyte in the Shimono-sawa route. Fragments of quartz and feldspar are enveloped by microlites. An arrow indicates an albite vein. (h) Chlorite veins (small arrows) cut pseudotachylyte. Dispersed fine-grained opaques are observed along a fracture in quartz (larger arrow). 


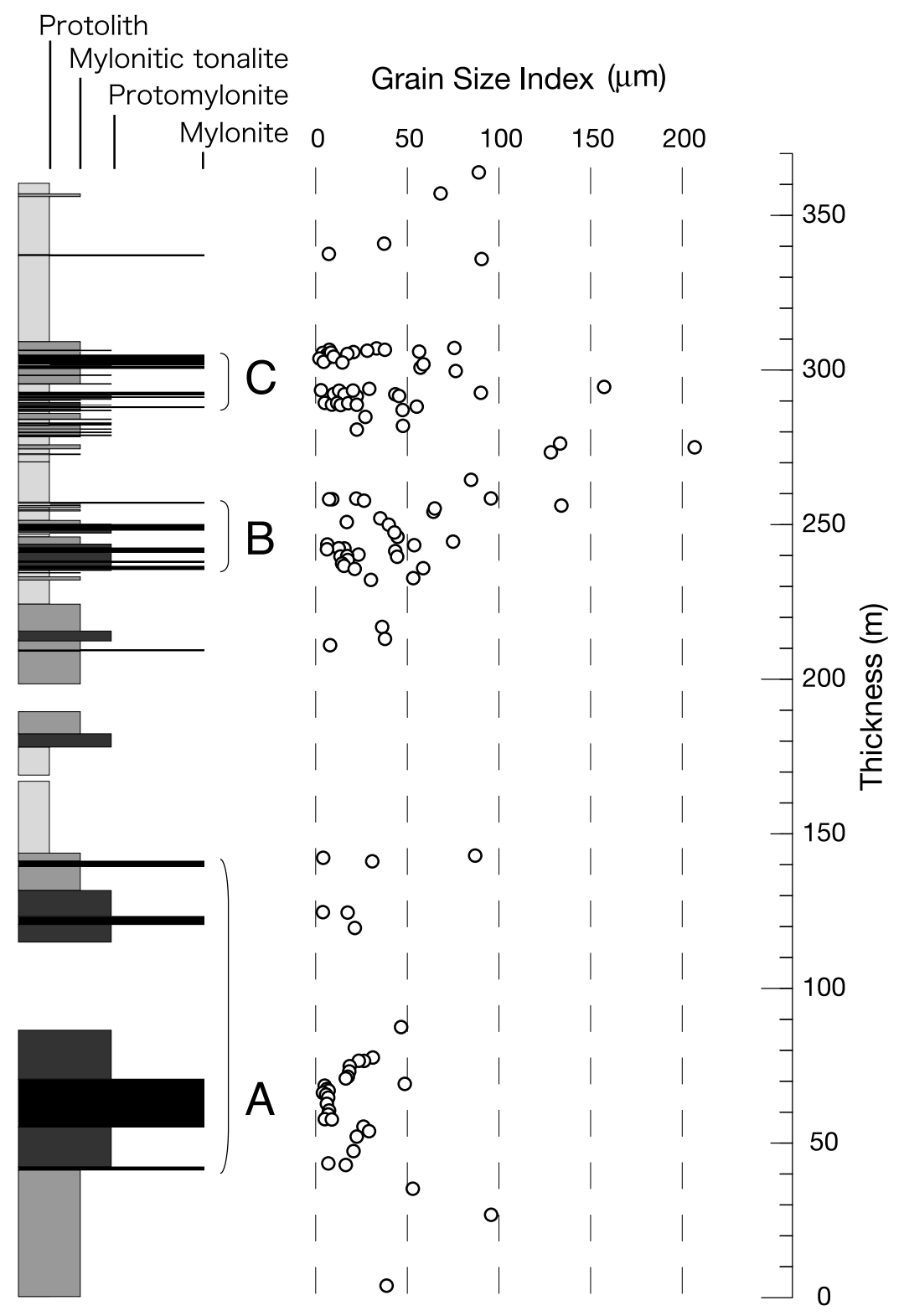

Fig. 3. A columnar section of the Shimono-sawa exposure (left) and the variety of grain-size index values across the columnar section (right) showing three clusters of localized shear zones A, B and C.

cally small in the protolith (Fig. 4). Chloritization of biotite and sericitization of plagioclase is conspicuous in most of the mylonite. The sum of modal contents for opaque and other minerals is less than $10 \%$ in all the samples. A decrease in quartz and an increase in sheet silicate contents in mylonite are also reported by Hippertt (1998) and Lonka et al. (1998).

\section{Occurrence of Pseudotachylytes in Mylonite Zones}

The occurrence of pseudotachylyte veins, which is evidences of seismic faulting, is not ubiquitous in the Shimono-sawa route. Most of the veins are concentrated within mylonite and protomylonite zones (Fig. 1). Large numbers of the pseudotachylyte veins are observed in the thickest mylonite zone in the route (shear zone A; Fig. 6(a)). Pseudotachylyte veins are more abundant in the center of the mylonite zone than in its margins (Fig. 6(b)). As shown in Fig. 6, the S-type tonalite contains many bodies of pelitic and psamitic gneiss or leucocratic rocks at outcrop scale. And some veins locate between these bodies and surrounding rocks.

The majority of the veins are $2-5 \mathrm{~mm}$ in thickness. Both generation and injection veins are composed of a cryptocrystalline matrix with very fine-grained opaque minerals and rounded to angular fragments of quartz and feldspar. Fragments of biotite are rare. Microlite spherules indicating a melt-quenched origin of the pseudotachylyte are observed in a vein of about $1 \mathrm{~cm}$ in thickness (Figs. 2(g) and (h)).

The generation veins of pseudotachylyte are mostly subparallel to C-surfaces of the surrounding mylonite (Fig. 2(f)). Veins cut clearly preexisting mylonitic structures. Wall-vein boundaries are generally sharp along the generation vein. Mylonitization of pseudotachylyte is not observed. The sense of slip along the pseudotachylyte veins is not clear due to the absence of shear sense indicators in 
(a)

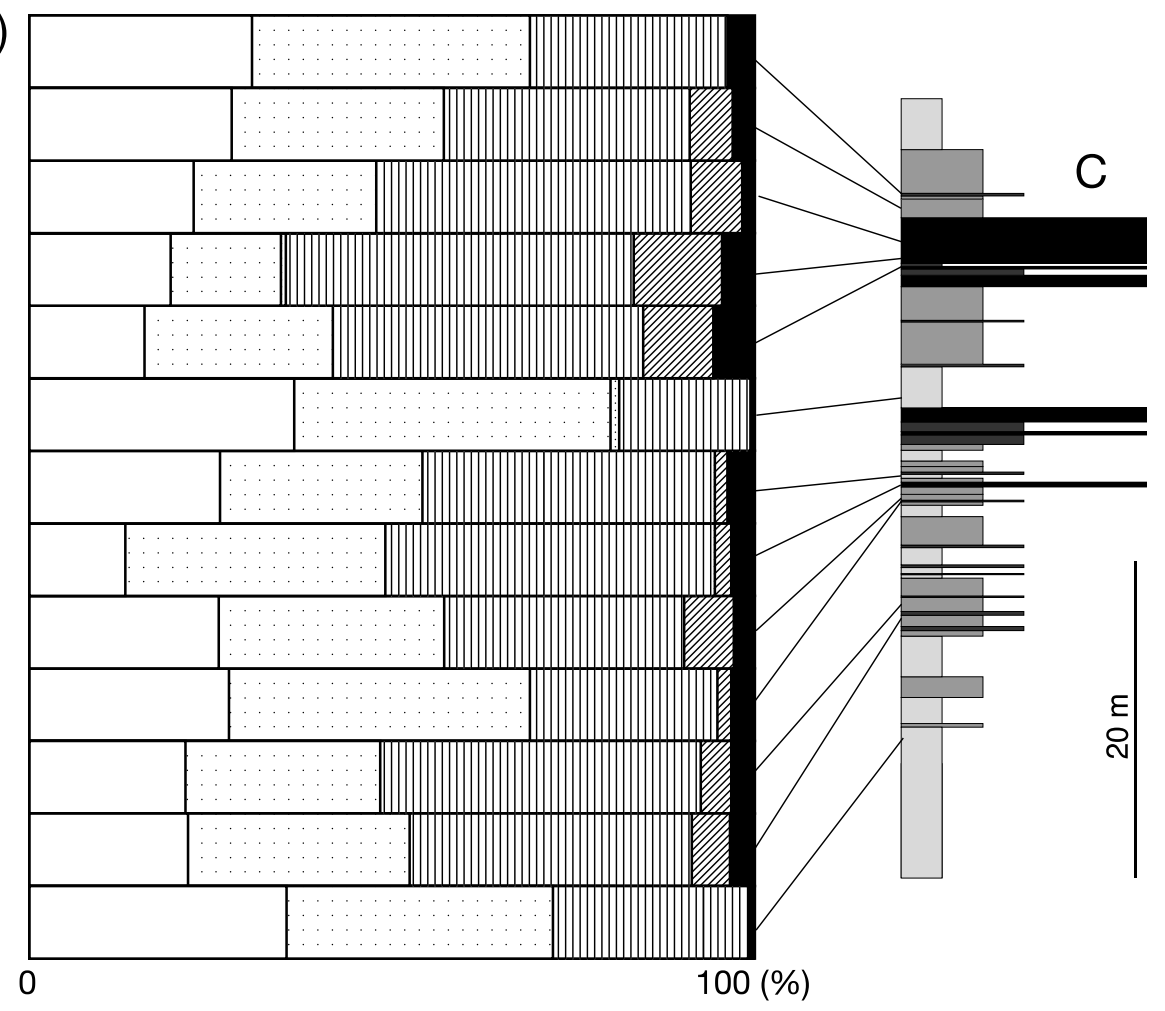

(b)
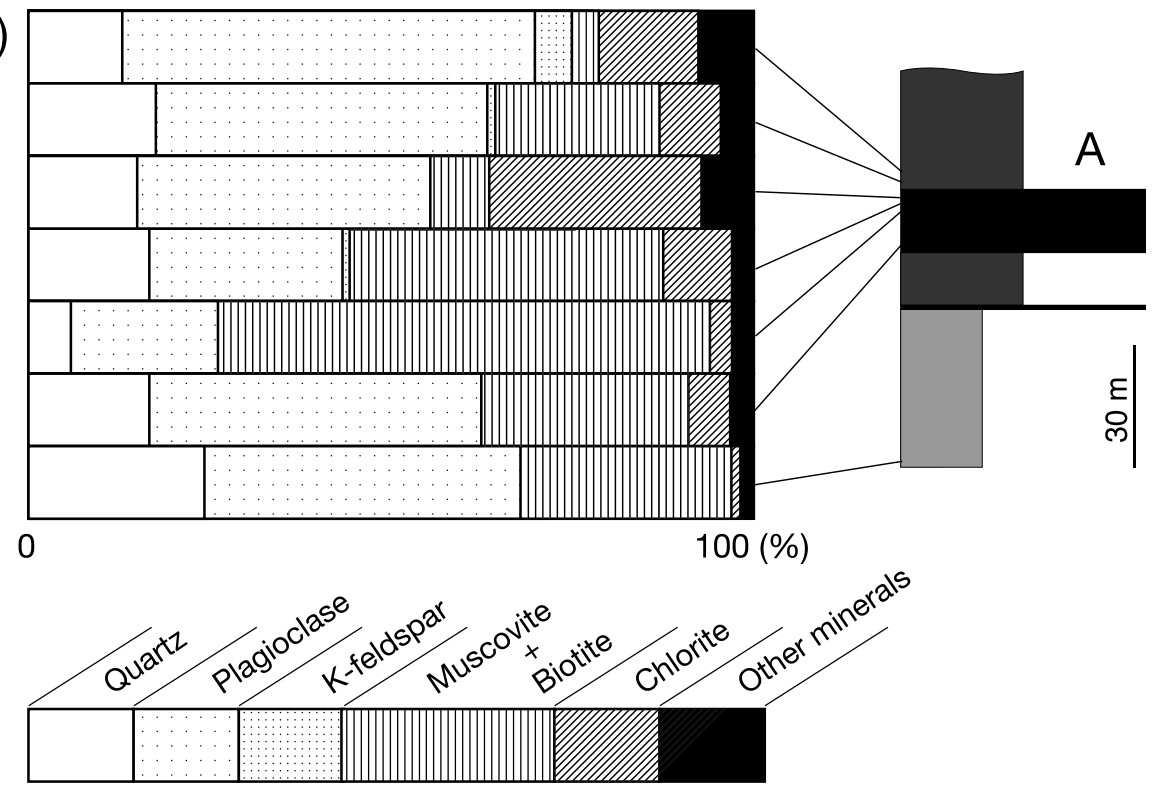

Fig. 4. Modal composition and sampling locality in the shear zone C (a) and in shear zone A (b).

generation veins, but striations subparallel to the stretching lineation in mylonites on the walls of generation veins indicate dominant dip slip. In the case of subparallel clustering of generation veins, most of them are separated by a few millimeters. Pseudotachylyte veins and surrounding mylonitic structures are cut by thinner mineral veins of chlorite, albite, and prehnite (Figs. 2(g) and (h)).

\section{Discussion}

Three clustered zones of mylonite indicate strain localization in ca. 20 to $100 \mathrm{~m}$ of thickness. The intervals separating them are ca. $90 \mathrm{~m}$ between shear zone $\mathrm{A}$ and $\mathrm{B}$, and ca. $30 \mathrm{~m}$ between shear zone $\mathrm{B}$ and $\mathrm{C}$, corresponding to the thickness of adjacent shear zones. More detailed observations of outcrops $\left(10^{-1}-10 \mathrm{~m}\right.$ scale) indicate that each major shear zone is composed of a number of minor shear zones alternating with weakly deformed zones. Furthermore, under the microscope, the mylonite is composed of alternating C-surfaces and domains between C-surfaces (Fig. 2(d)). These observations indicate that shear deformation is highly heterogeneous, and the spatial distributions of shear zones may be fractal from microscopic to a few hundred-meter scales.

A decreased quartz content accompanied with mylonitization is a relatively clear trend as compared with the increase of sheet silicate content (Fig. 5). As shown in Fig. 6, 

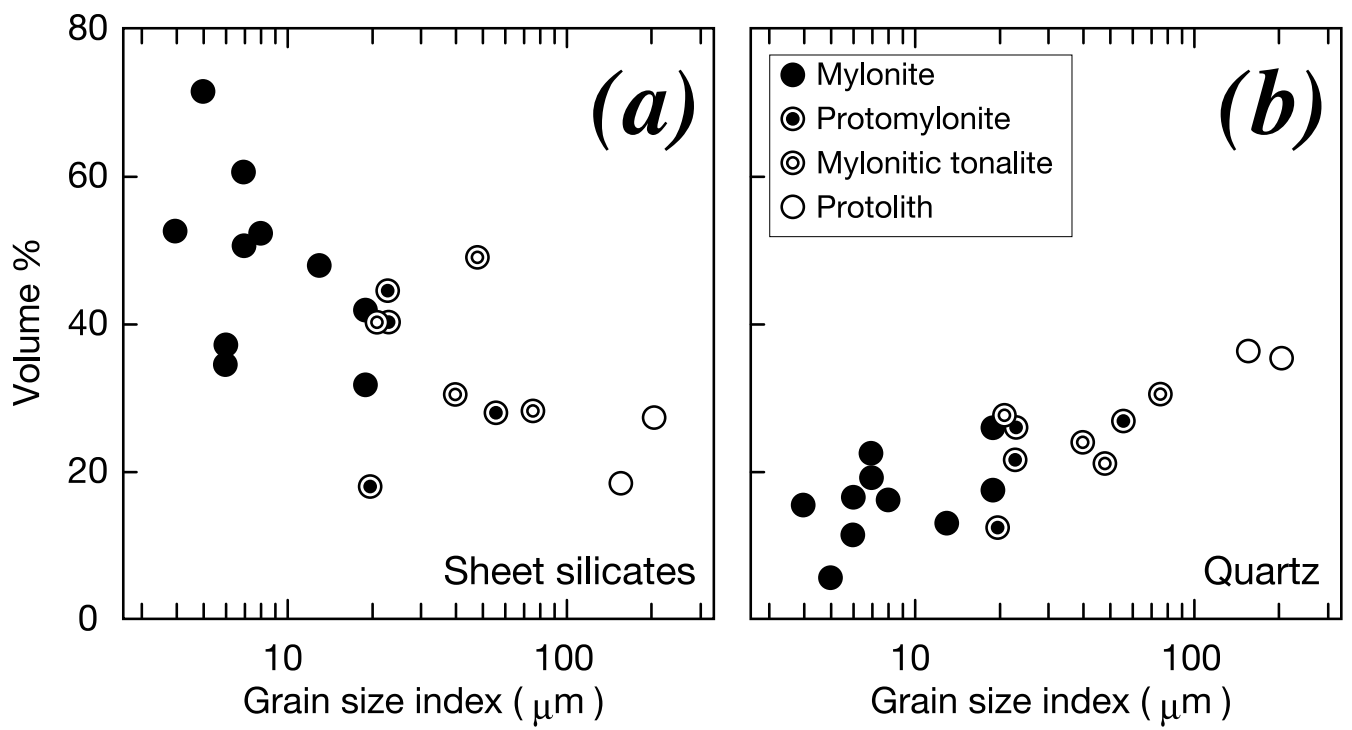

Fig. 5. Volumetric percentages of sheet silicates (a) and quartz (b) with respect to grain-size index values.

a)
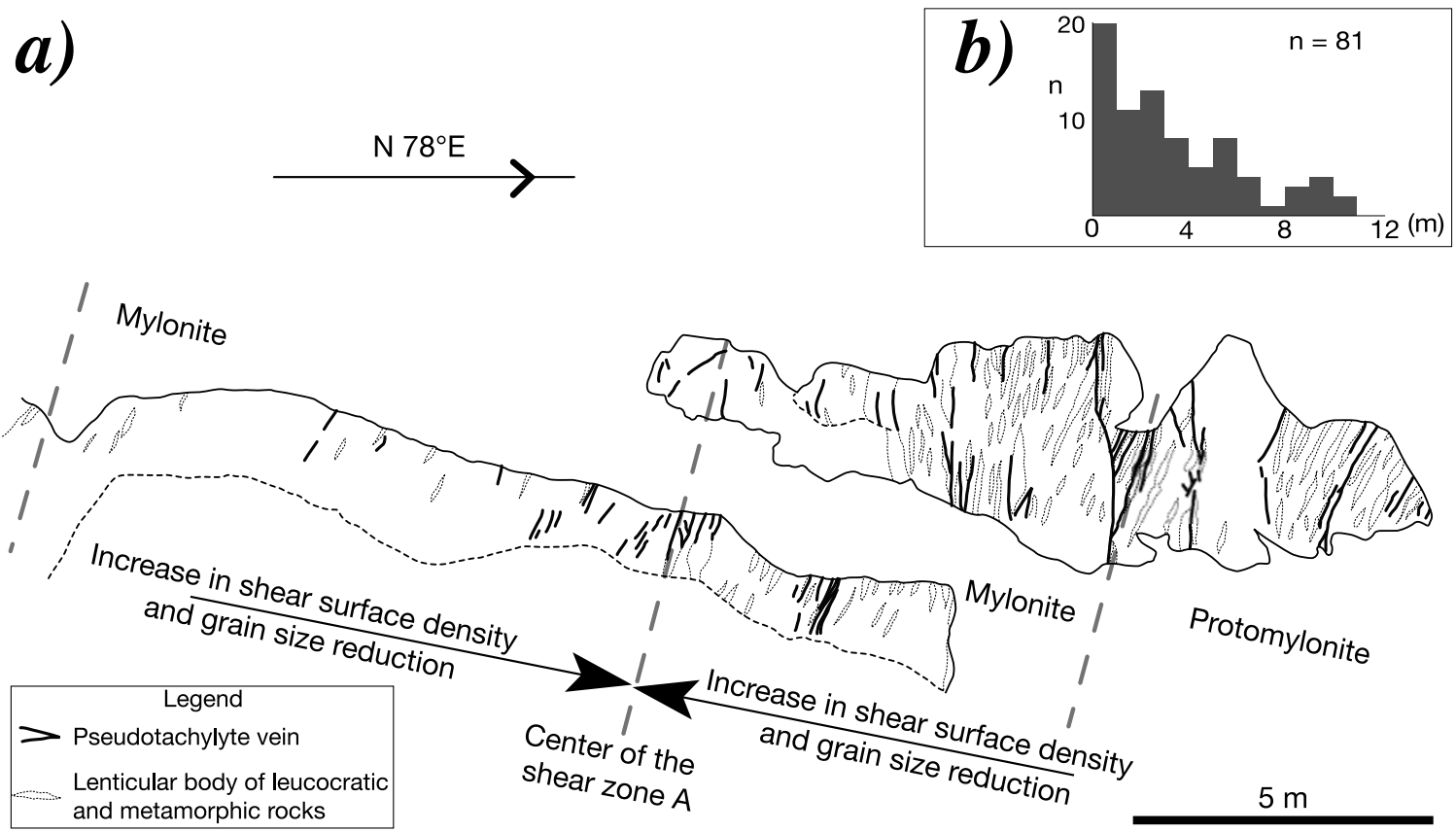

Fig. 6. (a) A sketch map showing locations of pseudotachylyte veins in shear zone A. (b) A histogram showing the occurrence frequency of pseudotachylyte veins with respect to distance from the center of shear zone A.

the homogeneous mineral modal composition of protolith in the Shimonosawa route is unrealistic assumption. One interpretation of the modal change from protolith to mylonite is that the sheet silicate rich portion was preferentially mylonitized discussed in larger geological map-scale (Tanaka et al., this issue). However, the changes in the modal composition may be attributed to the chemical reaction during the mylonitization. Characteristically small content of chlorite in protolith suggest that the retrogressive reaction of biotite occurred selectively in mylonitic shear zones during greenschist facies metamorphic condition. Conspicuous sericitization of plagioclase in mylonite also support the idea that water-assisted reactions preferentially occurred in localized mylonitic shear zones. Mylonitic shear zones in the Shimono-sawa route probably serve some water pathway or absorber in the lower crust. If so, it is possible that the decrease of quartz content in mylonite is partly due to the predominant dissolution of quartz during mylonitization (e.g., Hippertt, 1998; Lonka et al., 1998). Decreased quartz content certainly established more sheet silicate rich modal composition, and probably contributed to subsequent preferential mylonitization in the sheet silicate rich zone. The width of the mylonitic shear zones, therefore, indicates the maximum extent of zoned, heterogeneous water distribution that facilitated the retrogressive reaction during mylonitization. The maximum extent is about half the thickness of the few hundred meters crustal section exhumed in the Shimono-sawa route (Fig. 3). 
Pseudotachylyte veins are concentrated in and along thicker mylonite zones (Figs. 1 and 6), suggesting a structural control of seismogenic faulting at mylonitic shear zones. The crosscutting relationship between pseudotachylyte veins and mylonitic structures indicates that the pseudotachylyte generation (i.e., seismic slip) post-dated the mylonitization. Seismic slip with pseudotachylyte generation occurred along preexisting $\mathrm{C}$ - and $\mathrm{C}^{\prime}$-surfaces mainly composed of sheet silicates in the mylonite. Most of preexisting generation veins of pseudotachylyte seems to behave as hardly breakable layer on the basis of rare occurrence of juxtaposed pseudotachylyte veins. It is possible that densely developed alternative structures of sheet silicate and quartzo-feldspatic layer's in mylonite contributed to planner crack propagation preceding seismic slip. The lower strength of sheet silicates suggests that these minerals, rather than quartz and feldspar probably control crustal strength around the base of the upper crust. Conditions for crack propagation and the unstable slip of sheet silicates and layered sheet silicate/quartzofeldspathic composite mineral assemblages should be investigated by further realistic experimental study. This should take into account the spatial distribution of strain localization zones at micro- to macroscopic scales when the modeling of the seismogenic zone is being considered.

Alternative interpretation of observed clustering of pseudotachylyte veins in mylonite zones is that the all veins are injected from distant and hidden generation zone. In this case, the generation zone was located on the extension of mylonite zone providing pathway of many $\mathrm{C}$-surfaces for pseudotachylyte melts. Namely, the location of the generation zone was prepared by the preceding development of mylonite zone. The occurrence of pseudotachylyte veins and mylonitic rocks in the Shimono-sawa route presumably show the structural control of seismogenic faulting at mylonite zone.

We conclude that seismic slip in S-type tonalite at the base of the upper crust may be initiated in clustered zones of mylonite, and is accompanied by the intense development of C-surfaces, a grain size reduction and an increase in sheet silicate content.

Acknowledgments. This study was supported by a grant for a comprehensive research program on Flow and Slip Processes in and below Seismogenic Regions, sponsored by the Ministry of Education, Culture, Sports, Science, and Technology, Japan. We are grateful to Dr. K. Fujimoto of Tokyo Gakugei University for his helpful advice. Many thanks are also extended to members of the Board of Education of Samani Town, Hokkaido for their substantial support during fieldwork.

\section{References}

Hanmer, S. and C. Passchier, Shear-sense indicators: A review, Geol. Surv. Canada Pap., 90, 1-71, 1991.

Hippertt, J. F., Breakdown of feldspar, volume gain and lateral mass transfer during mylonitization of granitoid in a low metamorphic grade shear zone, Jour. Structural Geol., 20, 175-193, 1998.

Komatsu, M., T. Toyoshima, Y. Osanai, and M. Arai, Prograde and anatectic reactions in the deep arc crust exposed in the Hidaka metamorphic belt, Hokkaido, Japan, Lithos, 33, 31-49, 1994.

Lonka, H., K. Schulmann, and Z. Venera, Ductile deformation of tonalite in the Suomusjärvi shear zone, south-western Finland, Jour. Structural Geol., 20, 783-798, 1998.

Nicolas, A. and J. P. Poirier, Crystalline Plasticity and Solid State Flow in Metamorphic Rocks, 444 pp., Wiley, New York, 1976.

Owada, M., Y. Osanai, and H. Kagami, Rb-Sr isochron ages for hornblende tonalite from the southeastern part of the Hidaka metamorphic belt, Hokkaido, Japan: Implication for timing of peak metamorphism, Mem. Geol. Soc Japan, 47, 21-27, 1997.

Shimura, T., Intrusion of granitic magma and uplift tectonics of the Hidaka metamorphic belt, Hokkaido, Jour. Geol. Soc. Japan, 95, 1-20, 1992 (in Japanese with English abstract).

Sibson, R. H., Fault rocks and fault mechanisms, Jour. Geol. Soc. London, 133, 191-213, 1977.

Tanaka, H., K. Shimada, T. Toyoshima, T. Obara, and T. Niizato, Heterogeneous material distribution, an important reason for generation of strainlocalized mylonite and frictional slip zones in the Hidaka metamorphic belt, Hokkaido, Japan, Earth Planets Space, 56, this issue, 1227-1234, 2004.

Toyoshima, T., Tectonic evolution of the Hidaka metamorphic belt and its implication in late Cretaceous-middle Tertiary tectonics of Hokkaido, Japan, Jour. Fac. Sci., Niigata Univ., Ser. E, 8, 1-107, 1991.

Toyoshima, T., M. Komatsu, and T. Shimura, Tectonic evolution of lower crustal rocks in an exposed magmatic arc section in the Hidaka metamorphic belt, Hokkaido, northern Japan, The Island Arc, 3, 182-198, 1994.

Toyoshima, T., T. Obara, T. Niizato, H. Tanaka, K. Shimada, M. Komatsu, Y. Wada, and T. Koyasu, Pseudotachylytes, related fault rocks, asperities, and crustal structures in the Hidaka metamorphic belt, Hokkaido, northern Japan, Earth Planets Space, 56, this issue, 1211-1217, 2004.

Tullis, J., A. W. Snoke, and V. R. Todd, Penrose conference report on significance and petrogenesis of mylonitic rocks, Geology, 10, 227-230, 1982.

K. Shimada (e-mail: faultrockshimada@mac.com), H. Tanaka, T. Toyoshima, T. Obara, and T. Niizato 